\title{
Effects of replacing rapeseed meal with fava bean at 2 concentrate crude protein levels on feed intake, nutrient digestion, and milk production in cows fed grass silage-based diets
}

\author{
L. Puhakka, S. Jaakkola, I. Simpura, T. Kokkonen, and A. Vanhatalo ${ }^{1}$ \\ Department of Agricultural Sciences, PO Box 28, FI-00014, University of Helsinki, Finland
}

\begin{abstract}
The objective of this study was to evaluate the production and physiological responses of dairy cows to the substitution of fava bean for rapeseed meal at 2 protein supplementation levels in grass silage-based diets. We used 6 primiparous and 6 multiparous Finnish Ayrshire cows in a cyclic changeover trial with a $2 \times 3$ factorial arrangement of treatments. The experimental diets consisted of formic acid-treated timothy-meadow fescue silage and 3 isonitrogenous concentrates containing either rapeseed meal, fava bean, or a 1:1 mixture of rapeseed meal and fava bean at low and high inclusion rates, resulting in concentrate crude protein (CP) levels of 15.4 and $19.0 \%$ in dry matter. Silage dry matter intake decreased linearly when rapeseed meal was replaced with fava bean, the negative effect being more distinct at the high CP level than the low $(-2.3$ vs. $-0.9 \mathrm{~kg} / \mathrm{d}$, respectively). Similarly, milk and milk protein yields decreased linearly with fava bean, the change tending to be greater at the high CP level than the low. Yield of milk fat was lower for fava bean compared with rapeseed meal, the difference showing no interaction with CP level. Especially at the high CP level, milk urea concentration was higher with fava bean compared with rapeseed meal indicating better utilization of protein from the rapeseed meal. The apparent total-tract organic matter digestibility did not differ between treatments at the low CP level, but digestibility was higher for fava bean than for rapeseed meal at the high CP level. Plasma concentrations of essential amino acids, including methionine and lysine, were lower for fava bean than for rapeseed meal. Compared with rapeseed meal, the use of fava bean in dairy cow diets as the sole protein supplement decreased silage intake and milk production in highly digestible formic acid-treated grass silage-based diets.
\end{abstract}

Key words: fava bean, rapeseed meal, dairy cow, grass silage

Received January 21, 2016.

Accepted July 9, 2016.

${ }^{1}$ Corresponding author: aila.vanhatalo@helsinki.fi

\section{INTRODUCTION}

The self-sufficiency of protein used in animal feeding in Europe is low. High prices, traceability, and consumer concerns about the use of genetically modified protein feeds such as soybean meal in animal nutrition has brought out an interest in more economical and ecological ways of producing home-grown protein for animal feed markets. Fava bean (Vicia faba) is a suitable crop for temperate climate cultivation, and its use in crop rotations has several beneficial effects for land use and the environment, apart from its symbiotic fixing ability of atmospheric nitrogen gas with rhizobia (Nemecek et al., 2008; Jensen et al., 2010). Such low-protein feed self-sufficiency in Europe could be improved by increasing the cultivated area and use of grain legumes in animal feed. In addition to conventional cereal grains, dairy cow rations are commonly supplemented with soybean or rapeseed meal in corn- or grass silage-based diets. Rapeseed meal has been reported to be a superior protein source compared with soybean meal in grass silage-based dairy cow diets (Huhtanen et al., 2011), but the amount of rapeseed produced in northern Europe is inadequate to cover the high amount of protein needed for modern ruminant nutrition.

The relatively high content of CP (30\% in DM) and starch (38\% in DM) in fava bean (Luke, 2015) make it a potentially suitable protein and energy source for dairy cow feeding. However, the AA profile of fava bean protein is different from that of rapeseed or soybean. The concentration of His in fava bean is similar to that in rapeseed or soybean meal but the Met content is lower (Jezierny et al., 2010). Histidine is considered the firstlimiting AA in milk production in grass silage-based diets (Vanhatalo et al., 1999; Korhonen et al., 2000). Owing to the low concentration of sulfur-containing AA in fava bean protein, its use as a sole protein supplement in high-producing dairy cow rations may limit milk yield similarly to peas, as have been suggested by Vander Pol et al. (2008).

Another challenge of using fava bean in ruminant nutrition is the high rumen degradability of its $\mathrm{CP}$, which is over 0.80 in many feed evaluation systems (NRC, 
2001; INRA, 2004; Luke, 2015). Owing to the high rumen degradability of $\mathrm{CP}$, fava bean may be more suitable to low-protein forage, such as corn silage-based dairy cow rations (Wilkins and Jones, 2000). On the other hand, the rumen degradability of starch in fava bean is lower than that of cereal grains (Offner et al., 2003) and when fava bean is fed as a substitute for cereal grains, the site of starch digestion can partly shift from the rumen to the small intestine (Larsen et al., 2009). This may have a positive effect on the performance of dairy cows, because grass silage-based rations might lead to a shortage of glucose (Vanhatalo et al., 2003).

Data on the effects of feeding fava bean as a replacement especially for rapeseed meal in grass silage-based dairy cow diets is rather limited, to our knowledge. Substitution of either soybean or rapeseed meal with fava bean in supplemented cereal grain-based concentrate at a rate of 10 to $35 \%$ had no adverse effects on DMI, milk yields, or milk protein yields in early studies conducted on corn silage or brome hay diets (Ingalls and McKirdy, 1974; Ingalls et al., 1980), or in more recent studies conducted on corn silage-based TMR or oat hay diets (Melicharová et al., 2009; Tufarelli et al., 2012). In contrast, Mordenti et al. (2007) substituted soybean with a mixture of fava bean and pea in an alfalfa hay-based TMR diet and found a decrease in silage intake and milk yield. Milk yield also decreased when rapeseed was substituted with other grain legumes, such as peas, in grass silage-based diets (Vanhatalo et al., 2004).

The objectives of this study were to evaluate the nutritional value of fava bean as a replacement for rapeseed meal, and to determine the production and physiological responses of dairy cows fed 2 different amounts of fava bean in grass silage-based diets. We hypothesized that (1) total substitution of rapeseed meal with fava bean would decrease milk yield, but partial substitution may not affect milk yield; (2) the increasing level of $\mathrm{CP}$ in the concentrate would increase milk yield independently from the protein source used; and (3) the low concentration of Met in fava bean would limit yields of milk and milk protein compared with rapeseed meal.

\section{MATERIALS AND METHODS}

\section{Animals, Experimental Design, and Diets}

The experimental procedures were approved by the National Animal Ethics Committee in Finland. Six primiparous (127 $\pm 10.7 \mathrm{DIM})$ and 6 multiparous (103 \pm 19.2 DIM) Finnish Ayrshire cows were allocated randomly to a cyclic changeover trial (Davis and Hall,
1969) with 3 periods of $21 \mathrm{~d}$. The mean parity of the multiparous cows was 2.17. Cows were weighed on 2 consecutive days at the beginning of the experiment $(613 \pm 77.1 \mathrm{~kg}$ of BW for primiparous, and $645 \pm 76.0$ $\mathrm{kg}$ of BW for multiparous) and at the end $(620 \pm 62.9$ $\mathrm{kg}$ of BW for primiparous, and $604 \pm 70.7 \mathrm{~kg}$ of BW for multiparous). Two observers performed body condition scoring using a scale of 1 to 5 according to Edmonson et al. (1989) at the beginning and end of the experiment. The average BCS was 3.25 at both time points.

Six experimental concentrates were tested in a $2 \times 3$ factorial arrangement of treatments consisting of 2 concentrate CP levels (low and high), and 3 types of protein sources. The 3 cereal-based concentrates contained isonitrogenous amounts of rapeseed meal $(\mathbf{R})$, fava bean $(\mathbf{F})$, or a 1:1 mixture of rapeseed meal and fava bean (RF) at 2 concentrate CP levels of $15.4 \%$ (low) and $19.0 \%$ (high) in DM. Primiparous cows received $10 \mathrm{~kg}$ and multiparous cows $12 \mathrm{~kg}$ of concentrates as fed per day. Concentrates were given in equal amounts at $0600,0830,1230,1700$, and $1930 \mathrm{~h}$. The amounts of fava bean in the concentrate were 1.3 and $3.1 \mathrm{~kg}$ of $\mathrm{DM} / \mathrm{d}$ for primiparous and 1.6 and $3.7 \mathrm{~kg}$ of $\mathrm{DM} / \mathrm{d}$ for multiparous cows at the low and high CP levels, respectively. The amounts of rapeseed meal were 1.1 and $2.7 \mathrm{~kg}$ of $\mathrm{DM} / \mathrm{d}$ for primiparous and 1.4 and 3.2 $\mathrm{kg}$ of $\mathrm{DM} / \mathrm{d}$ for multiparous cows at the low and high CP levels, respectively. The ingredients and chemical composition of the concentrates are shown in Table 1. The pelleting process of the concentrates involved steam conditioning (steam temperature $100^{\circ} \mathrm{C}$ ) for 15 to $20 \mathrm{~min}$, during which the moisture content of the feed increased up to $18 \%$, pelleting in a die chamber where the temperature rose rapidly to $80^{\circ} \mathrm{C}$, and cooling and drying to gain a moisture content of $12 \%$ in the finished concentrate feeds.

Wilted grass silage was made from first-cut timothy (Phleum pratense) and meadow fescue (Festuca pratensis) sward grown at Helsinki $\left(60^{\circ} 10^{\prime} \mathrm{N}, 24^{\circ} 56^{\prime} \mathrm{E}\right)$ and ensiled in a bunker silo with formic acid-based additive (760 $\mathrm{g}$ of formic acid and $55 \mathrm{~g}$ of ammonium formate, AIV 2 Plus; Kemira Ltd., Helsinki, Finland) at a rate of $5 \mathrm{~L} / \mathrm{t}$ of fresh herbage. Grass silage was fed ad libitum 3 times a day, at 1030, 1500, and 1800 $\mathrm{h}$ to about $5 \%$ of orts. Orts were collected daily before the $1030 \mathrm{~h}$ feeding. During the experiment, cows were housed in individual tie stalls and had free access to fresh water and salt blocks. Daily feed intake was measured for each animal using an electronic feed intake monitoring system (Insentec BV, Marknesse, the Netherlands) equipped with separate concentrate troughs. Cows were milked twice daily, at 0600 and $1700 \mathrm{~h}$. 
Table 1. Ingredient and chemical composition of the experimental feeds

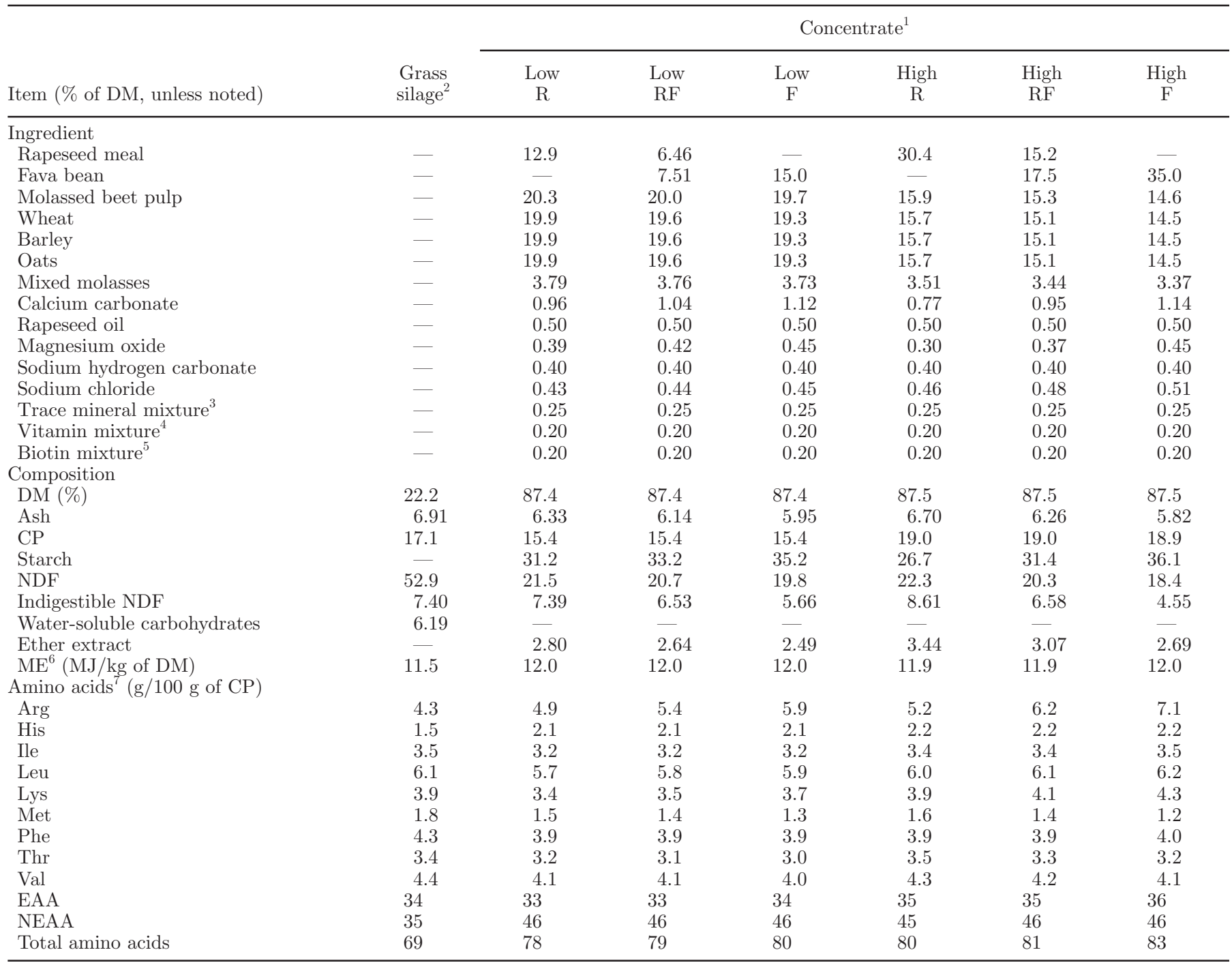

${ }^{1}$ Low $=$ CP $15.4 \%$ of DM; High = CP 19.0\% of DM; R = rapeseed meal; RF = 1:1 mixture of rapeseed and fava bean; $\mathrm{F}=$ fava bean.

${ }^{2}$ Mean fermentation characteristics of formic acid-treated grass silage: $\mathrm{pH} 3.79$; lactic acid, 4.11\% of DM; acetic acid, $1.70 \%$ of DM; propionic acid, $0.01 \%$ of DM; butyric acid, $0.05 \%$ of DM; ammonium N, $4.67 \%$ of total N.

${ }^{3} \mathrm{Ca}, 74.3 \mathrm{~g} / \mathrm{kg}$; Co, $360 \mathrm{mg} / \mathrm{kg}$; Cu, 6,253 mg/kg; Fe, $254 \mathrm{mg} / \mathrm{kg} ; \mathrm{I}, 1,922 \mathrm{mg} / \mathrm{kg} ; \mathrm{K}, 3.98 \mathrm{~g} / \mathrm{kg} ; \mathrm{Mn}, 4,991 \mathrm{mg} / \mathrm{kg} ; \mathrm{Mo} 0.25 \mathrm{mg} / \mathrm{kg} ; \mathrm{Se}, 140 \mathrm{mg} /$ $\mathrm{kg} ; \mathrm{Zn}, 37,024 \mathrm{mg} / \mathrm{kg}$; Raisioagro Ltd., Raisio, Finland.

${ }^{4}$ Vitamin A, 4,500 IU $/ \mathrm{g}$; vitamin $\mathrm{B}_{1}, 3.58 \mathrm{mg} / \mathrm{kg}$; vitamin $\mathrm{B}_{2}, 1.35 \mathrm{mg} / \mathrm{kg}$; vitamin $\mathrm{B}_{6}, 2.70 \mathrm{mg} / \mathrm{kg}$; biotin, $0.12 \mathrm{mg} / \mathrm{kg}$; vitamin $\mathrm{D}_{3}, 900 \mathrm{IU} / \mathrm{g}$; vitamin E, 4,516 mg/kg; folic acid, $0.41 \mathrm{mg} / \mathrm{kg}$; choline, $795 \mathrm{mg} / \mathrm{kg}$; niacin, $47.3 \mathrm{mg} / \mathrm{kg}$; pantothenic acid, $5.17 \mathrm{mg} / \mathrm{kg}$ (Raisioagro Ltd.).

${ }^{5} \mathrm{Ca}, 72.9 \mathrm{~g} / \mathrm{kg}$; Co, $0.09 \mathrm{mg} / \mathrm{kg} ; \mathrm{Cu}, 3.75 \mathrm{mg} / \mathrm{kg} ; \mathrm{Fe}, 258 \mathrm{mg} / \mathrm{kg} ; \mathrm{I}, 0.13 \mathrm{mg} / \mathrm{kg} ; \mathrm{K}, 4.31 \mathrm{~g} / \mathrm{kg} ; \mathrm{Mn}, 31.4 \mathrm{mg} / \mathrm{kg} ; \mathrm{Mo}, 0.27 \mathrm{mg} / \mathrm{kg} ; \mathrm{Se}, 0.15 \mathrm{mg} /$ $\mathrm{kg} ; \mathrm{Zn}, 25.5 \mathrm{mg} / \mathrm{kg}$; vitamin $\mathrm{B}_{1}, 3.46 \mathrm{mg} / \mathrm{kg}$; vitamin $\mathrm{B}_{2}, 1.31 \mathrm{mg} / \mathrm{kg}$; vitamin $\mathrm{B}_{6}, 2.62 \mathrm{mg} / \mathrm{kg}$; biotin, $360 \mathrm{mg} / \mathrm{kg}$; vitamin E, $10,015 \mathrm{mg} / \mathrm{kg} ;$ folic acid, $0.40 \mathrm{mg} / \mathrm{kg}$; choline, $770 \mathrm{mg} / \mathrm{kg}$; niacin, $45.8 \mathrm{mg} / \mathrm{kg}$; pantothenic acid, $5.00 \mathrm{mg} / \mathrm{kg}$ (Raisioagro Ltd.).

${ }^{6}$ Calculated according to Luke (2015).

${ }^{7} \mathrm{EAA}=$ sum of essential AA (Arg, His, Ile, Leu, Lys, Met, Phe, Thr, Trp, and Val). NEAA = sum of nonessential AA (Ala, Asn, Asp, Cys, Gln, Glu, Gly, Pro, Ser, and Tyr). Total AA = EAA + NEAA.

\section{Sample Collection and Measurements}

Individual feed intakes were recorded daily during the entire experiment, but only recordings from the last $7 \mathrm{~d}$ of each period were used for statistical analysis. Si- lage and concentrate samples were collected daily during the last $7 \mathrm{~d}$ of each experimental period, stored at $-20^{\circ} \mathrm{C}$ until thawed at room temperature, composited by period, mixed thoroughly, dried in a forced air oven at $50^{\circ} \mathrm{C}$ for $48 \mathrm{~h}$, ground through a $1-\mathrm{mm}$ screen, and 
analyzed for chemical composition. Fresh samples of silage were stored at $-20^{\circ} \mathrm{C}$ for analysis of fermentation quality.

Fecal samples were collected from the rectum, or from the ground when fresh, twice daily at 0800 and 1800 for $5 \mathrm{~d}$ at the end of each period to determine the apparent total-tract digestibility of nutrients using acid insoluble ash as an intrinsic digestibility marker (Van Keulen and Young, 1977). Samples were composited per animal and period and stored at $-20^{\circ} \mathrm{C}$. After each period, composited fecal samples were defrosted, mixed thoroughly, dried in a forced air oven $\left(60^{\circ} \mathrm{C} ; 48 \mathrm{~h}\right)$, ground through a $1.5-\mathrm{mm}$ screen and analyzed for chemical composition. Spot urine samples (300 mL/sample) were collected on d 17 and 18, between 1830 and $2030 \mathrm{~h}$ and 0530 and $0730 \mathrm{~h}$, respectively. Urine samples were collected by massaging the vulva, and after collecting, fresh samples were acidified immediately to reach $\mathrm{pH} 3$ or less with 10 $\mathrm{mL}$ of $\mathrm{H}_{2} \mathrm{SO}_{4}$. Samples were further diluted 1:10 with distilled water and stored at $-20^{\circ} \mathrm{C}$ until analyzed for total nitrogen, purine derivatives allantoin and uric acid, and creatinine, which was used as a urine volume marker.

The individual milk yield of each cow was recorded daily throughout the experiment, but only milk yields from the last $7 \mathrm{~d}$ of each experimental period were analyzed. Milk composition samples were collected from 4 consecutive milkings starting at the $1700 \mathrm{~h}$ milking on d 17. Samples were preserved with 2-bromo2-nitropropane-1,3-diol (Bronopol; Valio Ltd., Helsinki, Finland) and analyzed for milk fat, CP, lactose, and urea (MilkoScan 133B analyzer; Foss Electric A/S, Hillerød, Denmark) at a commercial laboratory (Valio Ltd., Seinäjoki, Finland).

Blood samples were collected from the coccygeal vessel at 0530,0830 , and $1130 \mathrm{~h}$ on the last day of each experimental period for plasma glucose, nonesterified fatty acids, BHB, acetic acid, insulin, glucagon, and AA analysis. Samples were collected into $10-\mathrm{mL}$ test tubes (Vacutainer; BD Medical, Franklin Lakes, NJ) containing anticoagulant agent (lithium heparin for acetic acid analysis and EDTA for other plasma metabolite and insulin analyses). After collection, samples were placed immediately on ice until centrifuged $(2,220 \times g$ for 10 min) to separate plasma. Plasma was stored in plastic tubes at $-20^{\circ} \mathrm{C}$.

\section{Chemical Analysis}

The DM and OM content of the feeds, concentration of acid insoluble ash, and in vitro OM digestibility were determined as described by Salin et al. (2012). Calcula- tions converting solubility to in vivo OM digestibility were performed by using the prediction equations described by Huhtanen et al. (2006). The concentration of $\mathrm{CP}$ was determined by the Kjeldahl method (AOAC International, 1995) with a Tecator Auto Digestion unit and copper as a catalyst and a Kjeltec Auto 2300 Analyzer (Foss). The NDF concentration was determined in the presence of sodium sulfite according to Van Soest et al. (1991) using a Tecator Fibertec system (1020 hot extractor and 1021 cold extractor; Foss). The results for NDF are expressed with residual ash. The indigestible neutral detergent fiber concentration was determined by incubating nylon bags (pore size of $17 \mu \mathrm{m}$ ) in the rumen of 2 dairy cows fed grass silage-based diets for $12 \mathrm{~d}$ according to Ahvenjärvi et al. (2000). Silage lactic acid (Barker and Summerson, 1941), water-soluble carbohydrates (Somogyi, 1945; Salo, 1965), ammonia nitrogen (McCullough, 1967), and ethanol contents were measured by colorimetric methods, using a spectrophotometer (Perkin-Elmer 55B, Shimadzu UV-VIS mini 1240; Shimadzu Europa GmbH, Duisburg, Germany). For ethanol analysis, an enzymatic kit (cat. no. 176290, Boehringer Mannheim, Mannheim, Germany) was used.

The VFA content of the silage was determined as follows. Silage extract was filtered through a $0.22-\mu \mathrm{m}$ filter. The filtrate $(150 \mu \mathrm{L})$ was diluted with $150 \mu \mathrm{L}$ of 2-ethylbutyric acid (internal standard) in acetonitrile. The diluted sample $(20 \mu \mathrm{L})$ was added to a vial, followed by $40 \mu \mathrm{L}$ of $100 \mathrm{~m} M$ pentafluorobenzylhydroxylamine in water-acetonitrile (1:1) solution. The solution was vigorously shaken for $5 \mathrm{~s}$ by a vortex shaker, and $40 \mu \mathrm{L}$ of $250 \mathrm{mM}$ activation reagent [1-ethyl-3-(3-dimethylaminopropyl)] carbodi-imide in ethanol containing $3 \%$ pyridine was added to the reaction vial. After shaking, the reaction vial was heated for $60 \mathrm{~min}$ at $60^{\circ} \mathrm{C}$. Liquid chromatographic analysis was performed using Waters Acquity ultra-performance liquid chromatography (UPLC) apparatus (Waters, Milford, MA) at a detection wavelength of $269 \mathrm{~nm}$. For analysis of the samples, a gradient program was performed. Starting conditions were $75 \%$ eluent A ( $0.1 \%$ formic acid in water) and $25 \%$ eluent B ( $0.1 \%$ formic acid in acetonitrile) for 0 to 1 min, lowering the volume of eluent A first to $40 \%$ over 1 to $8 \mathrm{~min}$, and then to $10 \%$ at $8 \mathrm{~min}$, and finally from 8.5 to 9 min the volume of eluent A was increased back to $75 \%$. Separations were performed using a Waters UPLC BEH C18 reverse phase column $(2.1 \times 100$ $\mathrm{mm}, 1.7 \mu \mathrm{m}$ ) at $45^{\circ} \mathrm{C}$, at a flow rate of $0.4 \mathrm{~mL} / \mathrm{min}$ from initiation to $1 \mathrm{~min}$. At $8 \mathrm{~min}$, the flow rate was increased to $0.45 \mathrm{~mL} / \mathrm{min}$, and from 8.5 to $9 \mathrm{~min}$ the flow rate was decreased linearly to $0.4 \mathrm{~mL} / \mathrm{min}$, staying 
constant until the end of the chromatographic run (10 min). Chromatograms were integrated and quantitated by the Empower 2 program (Waters).

Concentrates and feces were analyzed for DM, OM, $\mathrm{CP}, \mathrm{NDF}$, and acid insoluble ash using the same procedures as for silage. The starch content of concentrates and feces was determined as described by Salo and Salmi (1968). Total fat was analyzed with ether extraction and hydrolysis with $\mathrm{HCl}$ (SoxCap 2047 Hydrolysis Unit, Foss Soxtec 8000; Foss Analytical, Hillerød, Denmark). To determine the AA content of the silage and concentrates, samples were hydrolyzed as described in Korhonen et al. (2002) according to Directive 98/64/EC (European Commission, 1998). Hydrolyzed samples were analyzed by UPLC (Acquity UPLC, Waters) equipped with a BEH C18 column $(100 \mathrm{~mm} \times 2.1 \mathrm{~mm})$ according to the manufacturer's instructions. An Acquity PDA detector operating at a $260 \mathrm{~nm}$ wavelength was used to detect AA. Urine total nitrogen was determined by the Kjeldahl method. The purine derivatives allantoin and uric acid, as well as creatinine, were determined by UPLC (Acquity UPLC) according to George et al. (2006), lowering the flow rate to $0.6 \mathrm{~mL} / \mathrm{min}$.

Plasma glucose, nonesterified fatty acids, and insulin concentrations were determined as described by Salin et al. (2012), and glucagon as described by Selim et al. (2014). Commercial enzymatic kits were used to analyze BHB (Ranbut kit RB 1007; Randox Laboratories Ltd., Crumlin, UK) and acetic acid (Cat. no. 10148261035, Boehringer Mannheim GmbH/R-Biopharm, Mannheim, Germany) concentrations in plasma. Analysis for BHB was performed on an automatic chemistry analyzer (KONEPro Selective Chemistry Analyzer; Thermo Electron Oy, Vantaa, Finland), and analysis for acetic acid was performed using a UV-spectrophotometer (Shimadzu UV-VIS mini 1240, Shimadzu Europa GmbH) according to the manufacturer's instructions. For the plasma AA analysis, samples were precipitated using $10 \%$ sulfosalicylic acid and further analyzed by UPLC as described above for the hydrolyzed feed samples.

\section{Calculations}

The ME content of the experimental concentrates was calculated as the sum of the energy concentrations of the component ingredients according to Finnish feed tables (Luke, 2015). The ME concentration of the silage was calculated based on the digestible $\mathrm{OM}$ concentration in DM (D-value; Luke, 2015). The ECM was calculated according to Sjaunja et al. (1991). Energy requirements for maintenance $(\mathrm{MJ} / \mathrm{d})$ and milk production $(\mathrm{MJ} / \mathrm{kg}$ of ECM) were calculated as $\mathrm{BW}^{0.75} \times 0.515+5.15 \times$ ECM (Luke, 2015). Energy balance was calculated as the difference between ME intake and ME requirements for maintenance and milk production. A correction equation for associative effects of feeds was used when calculating ME intake (Luke, 2015). Changes in BW were ignored when the efficiency of ME utilization for milk production was calculated.

The content of MP for grass silage and concentrates was calculated according to Luke (2015). Whole-animal $\mathrm{N}$ balance $(\mathrm{g} / \mathrm{d})$ was calculated as $[\mathrm{N}$ intake, $\mathrm{g} / \mathrm{d}-(\mathrm{N}$ in milk, $\mathrm{g} / \mathrm{d},+\mathrm{N}$ excreted in feces and urine, $\mathrm{g} / \mathrm{d})$ ]. The efficiency of conversion of feed DM and the utilization of feed $\mathrm{N}$ were calculated for each cow by dividing mean milk yield by mean DMI and by dividing mean milk $\mathrm{N}$ output by mean $\mathrm{N}$ intake, respectively. The requirements of MP for maintenance and milk production were calculated according to Luke $(2015)$ as $\{(1.8 \times$ $\left.\mathrm{BW}^{0.75}+14 \times \mathrm{DMI}\right)+[(1.47-0.0017 \times \mathrm{ECM}) \times$ milk protein yield]\}. Changes in BW were ignored when the efficiency of utilization of MP for milk production was calculated.

Daily urine volume was estimated from daily urinary creatinine concentration as described by Valadares et al. (1999), with the exception that creatinine excretion rate was $25 \mathrm{mg} / \mathrm{kg}$ of $\mathrm{BW}$, determined according to total urine collection samples from our previous experiment (L. Puhakka et al., unpublished data). Estimated urine volume was used to calculate total daily nitrogen and purine derivative excretions. Total urinary purine derivative excretion was used to calculate microbial nitrogen flow from the rumen (Chen and Gomes, 1992).

\section{Statistical Analysis}

All data were analyzed using the MIXED procedure in SAS (version 9.3; SAS Institute Inc., Cary, NC). The model included the fixed effects of block, period, treatment, treatment carry-over, and the interaction of block $\times$ treatment. Cow within block was considered a random effect. The sums of squares of the treatment effects were further separated into single degree of freedom comparisons using orthogonal contrasts as follows: contrast $1=$ effect of concentrate CP level (low vs. high CP level), contrasts 2 and $3=$ effect of concentrate $\mathrm{CP}$ source (i.e. linear or quadratic effect of the protein source substitution level, respectively), and contrasts 4 and $5=$ interaction between concentrate $\mathrm{CP}$ level and linear or quadratic effect of the substituted protein source, respectively. Treatment effects were declared significant at $P \leq 0.05$. Differences at $P>0.05$ to 0.10 were considered a trend toward significance. 


\section{RESULTS}

\section{Composition of the Experimental Diets}

The ingredients used and the chemical composition of experimental concentrates and grass silage are presented in Table 1. The average $\mathrm{CP}$ concentration of the whole diet was 16.3 and $18.0 \%$ in DM at low and high $\mathrm{CP}$ levels, respectively. The starch concentration was higher in the $\mathrm{F}$ concentrate than in the $\mathrm{R}$ concentrate. The difference between $\mathrm{R}$ and $\mathrm{F}$ was 4.0 percentage points at the low $\mathrm{CP}$ level and 9.4 percentage points at the high CP level. The concentrations of NDF and indigestible NDF were lower in F concentrate than in $\mathrm{R}$ concentrate. Histidine concentration was similar among the concentrates, but Met concentration was lower and Lys concentration higher in $\mathrm{F}$ concentrate than in $\mathrm{R}$ concentrate.

\section{Feed Intake and Diet Digestibility}

Feed and nutrient intakes and the digestibility of the experimental diets are shown in Table 2. No orts were detected from concentrate feeding throughout the experiment. The substitution of $\mathrm{R}$ with $\mathrm{F}$ linearly decreased silage and total DMI and intakes of OM, CP, $\mathrm{NDF}, \mathrm{ME}$, and MP, and the effect was greater at the high than the low CP level $(P \leq 0.01$ for contrast 4$)$. The dietary intake of starch increased linearly when $\mathrm{R}$ was substituted with $\mathrm{F}$, the effects being greater at the high than the low CP level $(P<0.001$ for contrast 4$)$.

The apparent digestibility of DM and OM was unchanged at the low $\mathrm{CP}$ level but increased linearly when $\mathrm{R}$ was substituted with $\mathrm{F}$ at high $\mathrm{CP}$ level $(P \leq 0.04$ for contrast 4$)$. The digestibility of $\mathrm{CP}$ increased in a quadratic manner $(P=0.01$ for contrast 3$)$ at high $\mathrm{CP}$ level, but it was lower and remained unchanged at the low $\mathrm{CP}$ level when $\mathrm{R}$ was substituted with $\mathrm{F}$ ( $P=0.02$ for contrast 4$)$. The digestibility of NDF decreased in a quadratic manner $(P=0.05$ for contrast 3$)$ when $\mathrm{R}$ was substituted with F. Substitution of R with F resulted in a greater linear increase in the digestibility of starch at the high than at the low $\mathrm{CP}$ level $(P<0.001$ for contrast 4).

\section{Milk Production and Nutrient Utilization}

Substituting $\mathrm{R}$ with $\mathrm{F}$ linearly decreased $(P<0.001$ for contrast 2) yields of milk, ECM, milk CP, and lactose (Table 2). However, for yields of milk and milk protein, the effect tended to be greater at high than low CP level $(P \leq 0.10$ for contrast 4$)$. Similarly, milk fat yield tended to be lower $(P=0.06$ for contrast 2$)$ for $\mathrm{F}$ than R. Milk CP concentration decreased linearly $(P<$ 0.001 for contrast 2) when substituting $\mathrm{R}$ with $\mathrm{F}$, but we observed no differences in the milk fat and lactose concentrations between diets. Substitution of $\mathrm{R}$ with $\mathrm{F}$ linearly increased milk urea, and the effect tended to be greater at the high than at the low $\mathrm{CP}$ level $(P$ $=0.07$ for contrast 4 ). We observed no differences in calculated energy balance or energy utilization between diets. Utilization of MP decreased when $\mathrm{CP}$ level increased $(P=0.001$ for contrast 1$)$.

The substitution of $\mathrm{R}$ with $\mathrm{F}$ linearly decreased intake of $\mathrm{N}$, decreases being greater at the high than at the low CP level $(P \leq 0.01$ for contrast 4$)$ (Table 3 ). Nitrogen balance was negative and decreased linearly when $\mathrm{R}$ was replaced with $\mathrm{F}$ ( $P=0.04$ for contrast 2 ). Replacing $\mathrm{R}$ with $\mathrm{F}$ linearly decreased $\mathrm{N}$ secreted in milk $(P<0.001$ for contrast 2$)$, and the ratio of milk $\mathrm{N}$ :feed $\mathrm{N}$ was higher at the low than at the high $\mathrm{CP}$ level $(P<0.001$ for contrast 1$)$. Substitution of $\mathrm{R}$ with $\mathrm{F}$ led to quadratic changes $(P=0.01$ for contrast 3$)$ in the amount of $\mathrm{N}$ excreted in feces and in the ratio of feces N:feed N, the latter variable being also higher at the low than at the high $\mathrm{CP}$ level $(P<0.001$ for contrast 1 ). As the concentrate $\mathrm{CP}$ level increased, the $\mathrm{N}$ secretion in urine increased $(P<0.001$ for contrast 1). Substitution of $R$ with $F$ increased the ratio of urine $\mathrm{N}$ :feed $\mathrm{N}$ at the high $\mathrm{CP}$ level, but it remained unchanged at the low CP level $(P=0.01$ for contrast 4$)$.

We observed no significant differences between treatments in the urinary secretions of creatinine (mean 137 $\mathrm{mmol} / \mathrm{d}$; SEM 4.5) or total PD. However, substitution of $\mathrm{R}$ with $\mathrm{F}$ tended to bring about a linear decrease in urine allantoin, total purine derivative concentrations, and calculated microbial nitrogen flow at the high $\mathrm{CP}$ level, but they tended to remain unchanged at the low CP level $(P \leq 0.08$ for contrast 4$)$.

\section{Plasma Energy Metabolites, Hormones, and Amino Acids}

Plasma concentration of glucose increased $(P=0.02$ for contrast 1) when dietary CP level was increased, and it tended to increase linearly $(P=0.06$ for contrast 2 ) when $R$ was replaced with $F$ (Table 4 ). We observed no differences in plasma nonesterified fatty acids, BHB, or insulin concentrations between the treatments. Substitution of $\mathrm{R}$ with $\mathrm{F}$ increased plasma acetate in a quadratic manner $(P=0.05$ for contrast 3$)$ but led to a linear decrease in $(P=0.01$ for contrast 2$)$ plasma glucagon concentration.

Substitution of $\mathrm{R}$ with $\mathrm{F}$ led to a linear decrease in plasma concentrations of EAA and total AA $(P \leq 0.03$ 
EFFECT OF FAVA BEAN ON NUTRIENT USE AND MILK PRODUCTION

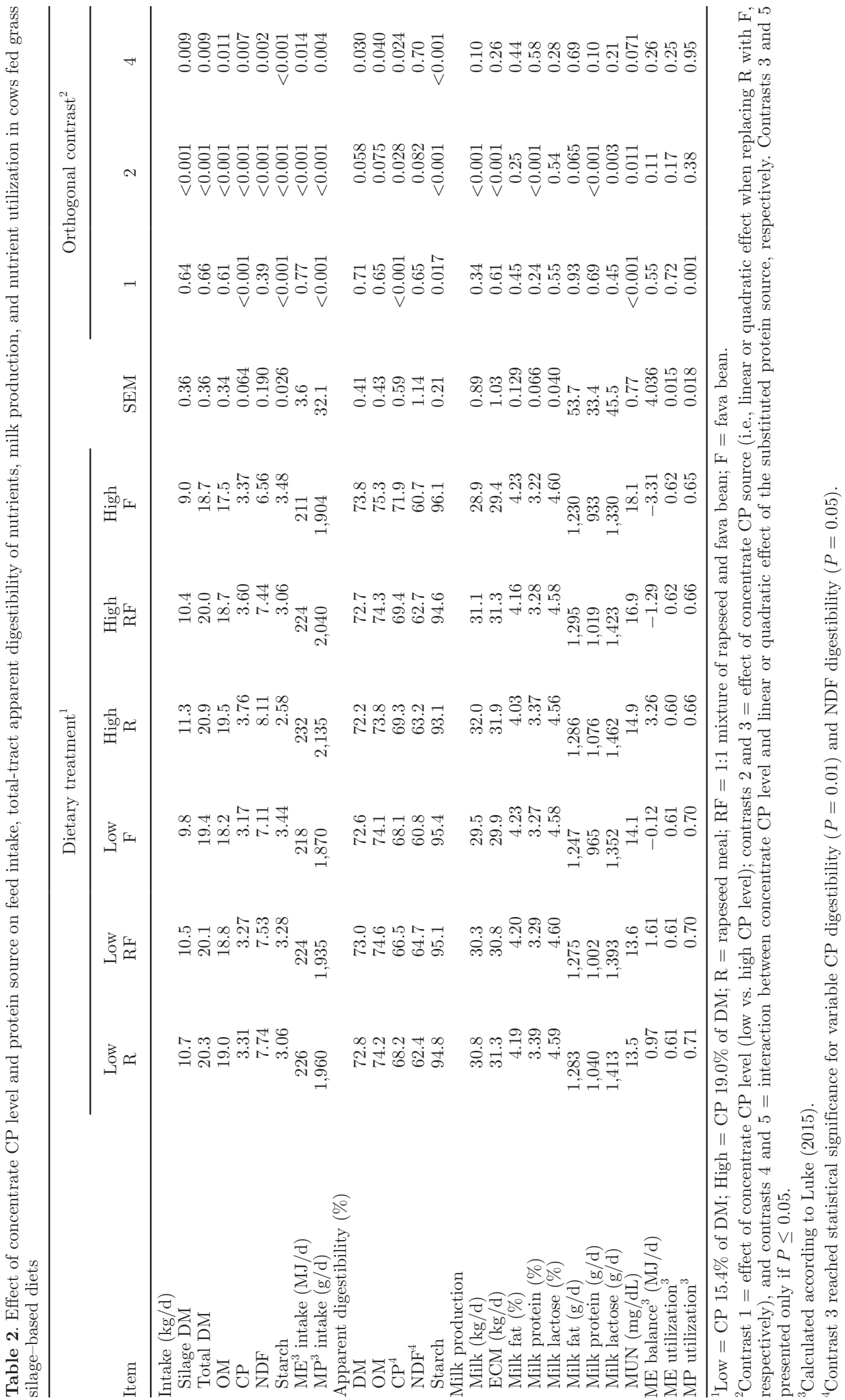


PUHAKKA ET AL.

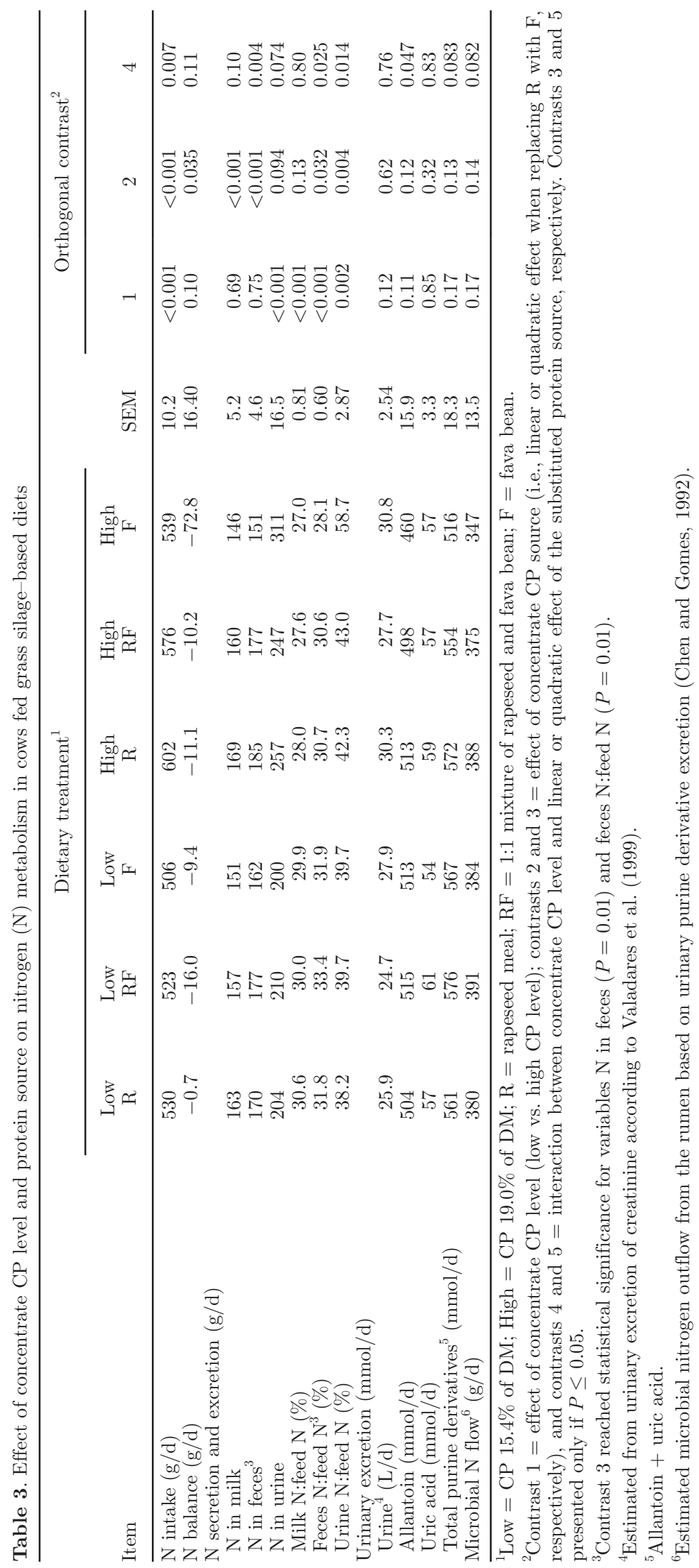


EFFECT OF FAVA BEAN ON NUTRIENT USE AND MILK PRODUCTION

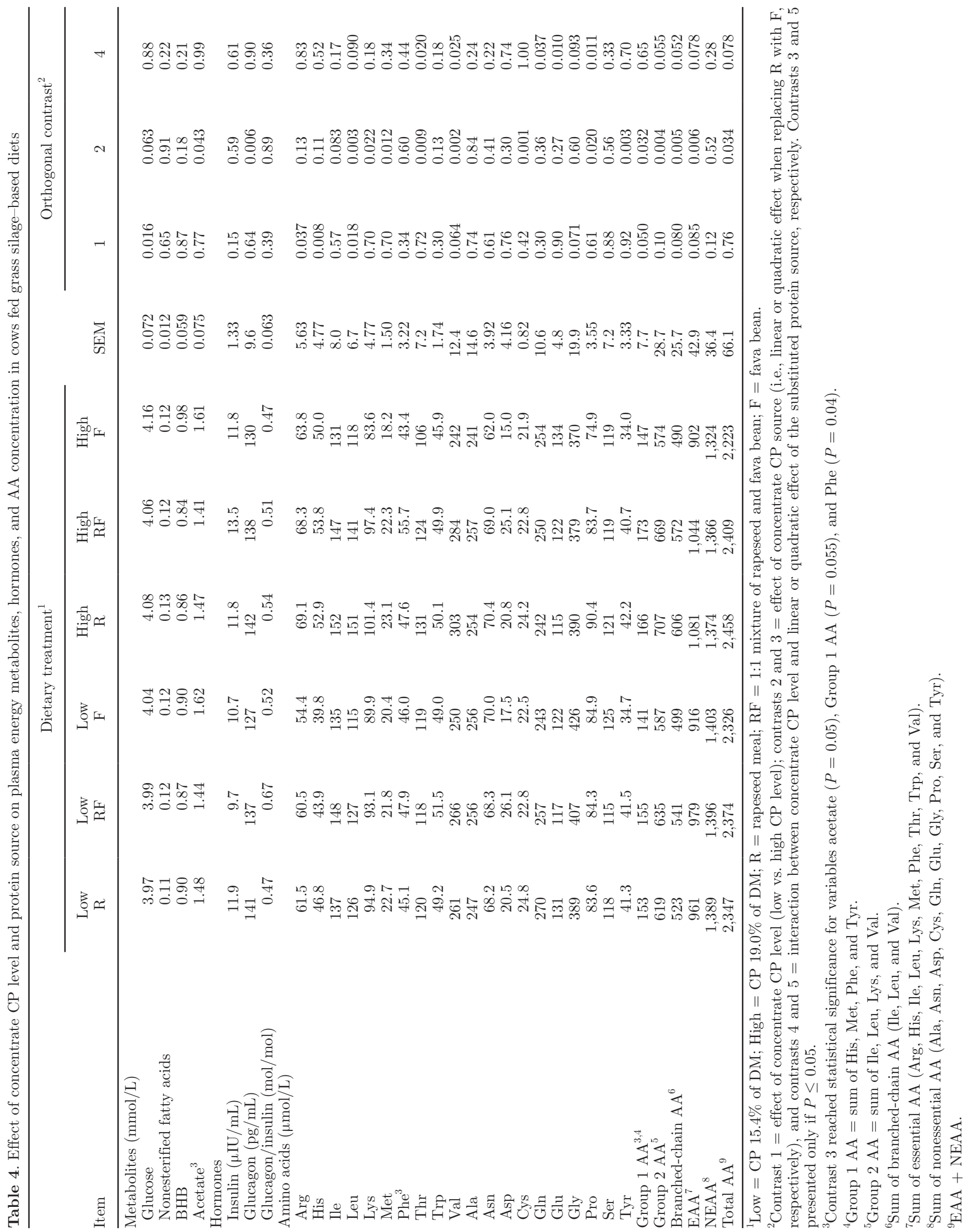


for contrast 2), but the concentration of total NEAA was unchanged between treatments (Table 4). Group 1 AA as calculated according to Lapierre et al. (2012) increased when dietary $\mathrm{CP}$ level increased $(P=0.05$ for contrast 1), and substitution of $\mathrm{R}$ with $\mathrm{F}$ tended to lead to a quadratic decrease $(P=0.06$ for contrast $3)$. Substitution of $\mathrm{R}$ with $\mathrm{F}$ tended lead to a linear decrease in plasma group 2 AA (Lapierre et al., 2012) and branched-chain AA, the decrease being greater at the high than at the low CP level $(P \leq 0.06$ for contrast 4). Of the individual AA, plasma Arg, His, and Leu increased $(P \leq 0.04$ for contrast 1$)$ when dietary $\mathrm{CP}$ increased. Substitution of $\mathrm{R}$ with $\mathrm{F}$ led to a linear increase in $(P \leq 0.02$ for contrast 2$)$ concentrations of plasma Leu, Lys, Met, Cys, and Tyr. Substitution of $\mathrm{R}$ with $\mathrm{F}$ led to a quadratic increase in plasma Phe $(P$ $=0.04$ for contrast 3). Plasma concentrations of Thr, Val, and Pro remained almost unchanged at the low CP level but they decreased linearly when $\mathrm{R}$ was replaced with $\mathrm{F}$ at the high $\mathrm{CP}$ level $(P \leq 0.02$ for contrast 4$)$. Concentrations of Gln and Glu decreased linearly when $\mathrm{R}$ was substituted with $\mathrm{F}$ at the low $\mathrm{CP}$ level but the opposite was found at the high CP level $(P \leq 0.04$ for contrast 4).

\section{DISCUSSION}

The primary aims of our research were to study production responses to fava bean compared with rapeseed meal on grass silage-based dairy cow diets. To define a suitable inclusion level of fava bean in terms of nitrogen and energy utilization of dairy cows, the experimental concentrates were given isonitrogenously at $2 \mathrm{CP}$ levels of 15.4 and $19.0 \%$ on DM basis. Respective CP levels for the whole diets were 16.3 and $18.0 \%$. Owing to the high starch concentration of fava bean, the $\mathrm{F}$ diet contained, on average, 6.7 percentage points more starch than did the $\mathrm{R}$ diet in this experiment. The NDF and indigestible NDF concentrations were higher in R compared with F. However, the calculated ME intake from the experimental concentrates were similar among the treatments. The maximum daily amount of fava bean fed to multiparous cows was $3.7 \mathrm{~kg}$ of DM in this trial. The palatability of the pelleted concentrates was good: no orts were detected from the concentrate feeding. In previous studies, even higher amounts of untreated fava bean have been fed (e.g., at a rate of $5.1 \mathrm{~kg} \mathrm{DM} / \mathrm{d}$; Mogensen et al., 2010) without reported disturbances in rumen function or animal health.

\section{Production Responses to Fava Bean}

Silage and total DMI increased for R but unexpectedly decreased for $\mathrm{F}$ with increased $\mathrm{CP}$ level. In other words, as $\mathrm{R}$ was substituted with $\mathrm{F}$, the silage DMI decreased 0.9 and $2.2 \mathrm{~kg} / \mathrm{d}$ at the low and high CP levels, respectively. The magnitude of the effects of $\mathrm{R}$ and $\mathrm{F}$ on total DMI were 0.036 and -0.042 as expressed per $1 \mathrm{~g} / \mathrm{kg}(\mathrm{DM})$ increase in dietary CP concentration, respectively. For rapeseed meal, this was in the range of the values obtained for untreated and heat-treated rapeseed meal (0.026 and 0.035; Huhtanen et al., 2011). We are not aware of any previous studies comparing $\mathrm{F}$ and $\mathrm{R}$ in grass silage-based dairy cow diets. Contrary to our results, using fava beans as a substitute for soybean meal (Ingalls and McKirdy, 1974; Ingalls et al., 1980; Tufarelli et al., 2012) or rapeseed meal (Ingalls and McKirdy, 1974) in diets based on alfalfa hay and corn silage or oat hay did not affect DMI. Positive responses in forage DMI obtained with goodquality protein supplements have often been attributed to increased diet digestibility (Huhtanen et al., 2011). This was not the case in the present study, because the nutrient digestibility of $\mathrm{R}$ did not increase with increased CP level. Instead, the increased DMI with R might be explained by the pull effect, as suggested by Huhtanen et al. (2011). That is, it may be a response to increased milk production enabled by a greater supply of essential AA or more balanced AA profile owing to increased $\mathrm{R}$, which in turn may have increased the energy demand and DMI of the R-fed cows. Nevertheless, reduced DMI with $\mathrm{F}$ may be associated with decreased NDF digestibility, as was found when R was substituted with $\mathrm{F}$ (discussed in more detail below). In addition, lower Met and presumably higher RDP (Luke, 2015) in $\mathrm{F}$ than $\mathrm{R}$ concentrates (Table 1) suggest an unbalanced AA profile for $\mathrm{F}$, which may also be associated with the observed low DMI with $\mathrm{F}$ diets. Recent studies have shown that supplementation of an MP-deficient diet with rumen-protected Lys, Met, and His (Lee et al., 2012) or rumen-protected Met and Lys (Broderick et al., 2015) increased DMI in corn and alfalfa silage-based diets.

Milk yield, as well as milk protein concentration and yield, decreased linearly when $\mathrm{R}$ was replaced with $\mathrm{F}$ on grass silage-fed cows in our study, confirming our hypothesis of the lower production potential of $\mathrm{F}$ compared with $\mathrm{R}$. The rank of $\mathrm{R}$ over $\mathrm{F}$ was predictable, given that the superiority of rapeseed protein over soybean protein has been proved on grass (Huhtanen et al., 2011; Gidlund et al., 2015), red clover-grass (Rinne et al., 2015), and corn silage alfalfa-based diets (Broderick et al., 2015). However, except for reduced milk protein concentration with fava bean compared with soybean in Ingalls et al. (1980), no difference in the production parameters have been found between fava bean and rapeseed meal (Ingalls and McKirdy, 1974) or fava bean and soybean meal (Ingalls and McKirdy, 1974; 
Tufarelli et al., 2012). Differences in the composition of the basal diets and milk production potential of cows between experiments may account for the differences in findings.

Our second hypothesis of increased production response to added protein, regardless of the protein source used, was not demonstrated. In fact, milk yield responses to concentrate $\mathrm{CP}$ level tended to depend on the protein source. As concentrate CP level increased (low vs. high), milk yield increased for R (30.8 vs. 32.0 $\mathrm{kg} / \mathrm{d}$ ) but decreased for F (29.5 vs. $28.9 \mathrm{~kg} / \mathrm{d})$. We found a similar tendency for milk protein yield. Even so, the calculated daily milk yield response to a $1-\mathrm{kg}$ increase in $\mathrm{CP}$ intake was relatively low: $2.4 \mathrm{~kg}$ for $\mathrm{R}$ per $1 \mathrm{~kg}$ of CP compared with $3.41 \mathrm{~kg}$ for untreated rapeseed meal reported for high-yielding cows by Huhtanen et al. (2011). The same was true for the milk protein yield response of $72 \mathrm{~g}$ per $1 \mathrm{~kg}$ of $\mathrm{CP}$ for $\mathrm{R}$, compared with $136 \mathrm{~g}$ obtained for untreated rapeseed meal in the metaanalysis by Huhtanen et al. (2011). This finding may be because high-quality grass silage (digestible $\mathrm{OM}$ in DM $71.6 \%$ ) contains high concentration of ME, which enabled readily efficient microbial protein synthesis in the present study. Lower-than-expected production responses to added rapeseed meal have also been found in recent studies conducted with cows fed highly digestible grass silage TMR (Gidlund et al., 2015) or a red clover-grass silage-based diet (Rinne et al., 2015). The negative milk and milk protein production responses to added $\mathrm{F}$ were obviously in part due to decreased silage DMI in these diets. Previous studies (Leonardi et al., 2003; Olmos Colmenero and Broderick, 2006) conducted with alfalfa and corn silage-based diets have shown that increasing the dietary $\mathrm{CP}$ content with soybean meal from $16.1-16.7 \%$ to $18.4-19.4 \%$ did not improve milk yield, in agreement with our results for F. The tendency for a linear increase in milk urea when replacing $\mathrm{R}$ with $\mathrm{F}$ at the high $\mathrm{CP}$ level suggests that increasing dietary $\mathrm{CP}$ with $\mathrm{F}$ impaired utilization of feed protein. Therefore, feeding a higher amount of $\mathrm{CP}$ derived from fava bean had no benefit for milk production in this study.

\section{Physiological Responses to Fava Bean}

The increase in $\mathrm{DM}$ and $\mathrm{OM}$ digestibility in $\mathrm{F}$ at the high CP level was probably due to increased dietary proportions of concentrate and highly digestible starch, because of decreased silage DMI. In general, protein supplementation increases NDF digestibility by activating the cellulolytic bacteria (Hoover, 1986), and because the indigestible NDF content of $\mathrm{F}$ was lower than that of $\mathrm{R}$, the NDF digestibility of $\mathrm{F}$ was not expected to be lower than that of R. Because the possibility of a RDP shortage in the experimental diets can be excluded owing to the dietary $\mathrm{CP}$ concentration above $16 \%$ in DM, another explanation for the reduced NDF digestibility with $\mathrm{F}$ might be the relatively high amount of easily fermentable carbohydrates available in the $\mathrm{F}$ diets. High amounts of easily fermentable substances, such as starch and soluble sugars, may decrease the ruminal $\mathrm{pH}$ and increase concentrations of rumen VFA, negatively affecting cellulolytic microbial activity (Mould et al., 1983). Such reduced rumen $\mathrm{pH}$ on $\mathrm{F}$ diets cannot be completely excluded, given that the silage used was highly digestible formic acid-treated silage and the proportions of forage NDF in the $\mathrm{F}$ diets were not higher than $27 \%$ at the low and $26 \%$ at high $\mathrm{CP}$ levels, respectively. On the other hand, the intake of fava bean was moderate in this experiment, and starch in grain legumes has lower rumen digestibility than starch in cereal grains (Offner et al., 2003; Larsen et al., 2009).

Higher starch content in $\mathrm{F}$ than in $\mathrm{R}$ may have increased starch digestion in the small intestine, because the total starch digestibility of $\mathrm{F}$ was higher than that of R. Consequently, glucose absorption from the intestine was probably increased in F, supported by higher plasma glucose concentration with $\mathrm{F}$ than with $\mathrm{R}$. On the other hand, plasma glucose was also increased in R, suggesting that higher $\mathrm{CP}$ intake may have increased the use of amino acids as precursors for gluconeogenesis. This may have been specific to $R$, because the decreased plasma glucagon in $\mathrm{F}$ might indicate that the increased intestinal glucose supply with F inhibited gluconeogenesis in the liver. One of the primary effects of glucagon in ruminants is to increase hepatic glucose synthesis (Brockman, 1978). The decrease of gluconeogenesis in $\mathrm{F}$ is further supported by lower $\mathrm{ME}$ intake of cows in $\mathrm{F}$ than $\mathrm{R}$, and the fact that there is a generally positive relationship between energy intake and gluconeogenesis (Huntington et al., 2006). Rumen fermentation was not measured in the present study, but higher plasma acetate with $\mathrm{F}$ than $\mathrm{R}$ at both $\mathrm{CP}$ levels suggests that replacing $\mathrm{R}$ with $\mathrm{F}$ favored acetatetype fermentation in the rumen, in line with the reduced NDF digestibility of $\mathrm{F}$ in this study. This finding is supported by results of Ingalls and McKirdy (1974), which show that increasing proportions of fava bean in the concentrate was associated with increased acetate to propionate ratio in the rumen.

The $\mathrm{N}$ balance of cows was considerably more negative with $\mathrm{F}$ than with $\mathrm{R}$, presumably due to lower silage DMI. However, because we did not perform total collection of feces and urine in the present study, $\mathrm{N}$ balance results should be interpreted with caution. Olmos 
Colmenero and Broderick (2006) reported that the elevation of the dietary CP concentration level increased linearly urinary allantoin and total purine derivative excretion until the threshold of $16.5 \%$ of the dietary CP concentration was reached. This indicates that there were no elevations in bacterial nitrogen formation and hence, no benefits to exceeding this dietary CP level. Likewise, in the present study, we did not observe an increase in allantoin or total purine excretion and microbial nitrogen flow when the $\mathrm{CP}$ level of the diets was increased from 16.3 to $18.0 \%$. In fact, microbial $\mathrm{N}$ flow diminished due to decreased DMI in F, when the dietary CP level was increased. Increasing dietary $\mathrm{CP}$ level elevated the proportion of $\mathrm{N}$ excreted in the urine, regardless of the protein source used. However, the highly increasing proportion of $\mathrm{N}$ excreted in urine when $\mathrm{R}$ was substituted with $\mathrm{F}$ at high $\mathrm{CP}$ level showed that protein from $\mathrm{R}$ was used much more efficiently than protein from $\mathrm{F}$.

Higher plasma concentrations of EAA with $\mathrm{R}$ than $\mathrm{F}$, including branched-chain AA and most of the individual EAA, suggest that $\mathrm{R}$ diets provided more absorbable EAA for milk protein synthesis than $\mathrm{F}$ diets. This was in line with the increased milk and milk protein yields of $\mathrm{R}$ diets. Martineau et al. (2013, 2014) demonstrated that rapeseed meal increased the absorption of EAA responsible for increased milk protein secretion and the increased apparent $\mathrm{N}$ efficiency was obtained with rapeseed diets.

Histidine is considered the first limiting AA in grass silage- and cereal-based diets (Vanhatalo et al., 1999; Korhonen et al., 2000). In the present study, the plasma concentration of His was relatively high at both $\mathrm{CP}$ levels, suggesting that there was no shortage of His supply with any of the experimental diets. However, the plasma concentration of Lys and sulfur-containing AA such as Met and Cys decreased when $\mathrm{R}$ was replaced with $\mathrm{F}$, possibly reflecting the low concentration of sulfur-containing AA in $\mathrm{F}$ and presumably the higher rumen degradability of $\mathrm{F}$ (Luke, 2015). The deficiency of these AA in F diets may have resulted in an unbalanced AA profile in the digesta entering to the small intestine, leading to limited milk production in $\mathrm{F}$ diets.

\section{CONCLUSIONS}

Substitution of rapeseed meal with fava bean in grass silage-based dairy cow diets resulted in lower silage DMI and lower yields of milk, ECM, and milk protein. Silage DMI and milk production tended to increase with the rapeseed-only diet $(\mathrm{R})$ but decrease in the fava bean-only diet $(\mathrm{F})$ when the dietary $\mathrm{CP}$ concentration increased. The lower silage DMI in $\mathrm{F}$ at the high $\mathrm{CP}$ level resulted in higher digestibility of nutrients, except for NDF. Nitrogen balance was considerably lower, and the proportion of $\mathrm{N}$ excreted in urine was higher in $\mathrm{F}$ than with $\mathrm{R}$, indicating more efficient use of protein from $\mathrm{R}$ than $\mathrm{F}$. The reduced plasma concentration of AA such as Lys and sulfur-containing amino acids Met and Cys with $\mathrm{F}$ diets suggests that a limited supply of these AA may have contributed to impaired DMI and milk production. Hence, the reason for the distinctive decrease in silage DMI at high CP level in F may be limited AA supply to energy ratio at the tissue level. However, the differences between $\mathrm{R}$ and $\mathrm{F}$ in the production and physiological responses of the dairy cows were smaller at the diet CP level of $16.3 \%$ than $18.0 \%$. Based on the results of this experiment, we conclude that use of fava bean as the sole protein source in dairy cow diets may lower silage intake and decrease milk production.

\section{ACKNOWLEDGMENTS}

The authors acknowledge Juha Suomi and his staff for the care of the experimental animals in Viikki research farm and the laboratory staff in the Department of Agricultural Science of University of Helsinki. This work was funded in part by the Finnish Ministry of Agriculture and Forestry and Raisioagro Ltd. (Raisio, Finland), and a PhD studentships from the Raisio Science Foundation (Raisio, Finland) and August Johannes and Aino Tiura Agricultural Science Foundation.

\section{REFERENCES}

Ahvenjärvi, S., A. Vanhatalo, P. Huhtanen, and T. Varvikko. 2000 Determination of reticulo-rumen and whole-stomach digestion in lactating dairy cows by omasal canal and duodenal sampling. Br. J. Nutr. 83:67-77.

AOAC International. 1995. Official Methods of Analysis. 16th ed. AOAC International, Arlington, VA.

Barker, S. B., and W. H. Summerson. 1941. The colorimetric determination of lactic acid in biological materials. J. Biol. Chem. 138:535-554.

Brockman, R. P. 1978. Roles of glucagon and insulin in the regulation of metabolism in ruminants - A review. Can. Vet. J. 19:55-62.

Broderick, G. A., A. P. Faciola, and L. E. Armentano. 2015. Replacing dietary soybean meal with canola meal improves production and efficiency of lactating cows. J. Dairy Sci. 98:5672-5687. http:// dx.doi.org/10.3168/jds.2015-9563.

Chen, X. B., and M. J. Gomes. 1992. Estimation of microbial protein supply to sheep and cattle based on urinary excretion of purine derivatives: An overview of technical details. Int. Feed Res. Unit, Occasional Publ. Rowett Research Institute, Aberdeen, UK.

Davis, A. W., and W. B. Hall. 1969. Cyclic change-over designs. Biometrika 56:283-293. http://dx.doi.org/10.1093/ biomet/56.2.283.

Edmonson, A. J., I. J. Lean, L. D. Weaver, T. Farver, and G. Webster. 1989. A body condition scoring chart for Holstein cows. J. Dairy Sci. 72:68-78. http://dx.doi.org/10.3168/jds.S00220302(89)79081-0. 
European Commission. 1998. Commission Directive 98/64/EC. Community methods of analysis for the determination of amino acids, crude oils and fats, and olaquindox in feedingstuffs and amending directive 71/393/EEC. Off. J. European Communities L 257:4-23.

George, S. K., M. T. Dipu, U. R. Mehra, P. Singh, A. K. Verma, and J. S. Ramgaokar. 2006. Improved HPLC method for the simultaneous determination of allantoin, uric acid and creatinine in cattle urine. J. Chromatogr. B Analyt. Technol. Biomed. Life Sci. 832:134-137. http://dx.doi.org/10.1016/j.jchromb.2005.10.051.

Gidlund, H., M. Hetta, S. J. Krizan, S. Lemosquet, and P. Huhtanen. 2015. Effects of soybean meal or canola meal on milk production and methane emissions in lactating dairy cows fed grass silage-based diets. J. Dairy Sci. 98:8093-8106. http://dx.doi. org $/ 10.3168 /$ jds.2015-9757.

Hoover, W. H. 1986. Chemical factors involved in ruminal fiber digestion. J. Dairy Sci. 69:2755-2766. http://dx.doi.org/10.3168/jds. S0022-0302(86)80724-X.

Huhtanen, P., M. Hetta, and C. Swensson. 2011. Evaluation of canola meal as a protein supplement for dairy cows: A review and a meta-analysis. Can. J. Anim. Sci. 91:529-543. http://dx.doi. org/10.4141/CJAS2011-029.

Huhtanen, P., J. Nousiainen, and M. Rinne. 2006. Recent developments in forage evaluation with special reference to practical applications. Agric. Food Sci. 15:293-323. http://dx.doi. org $/ 10.2137 / 145960606779216317$.

Huntington, G. B., B. D. L. Harmon, and C. J. Richards. 2006. Sites, rates, and limits of starch digestion and glucose metabolism in growing cattle. J. Anim. Sci. 84:E14-E24.

Ingalls, J. R., and J. A. McKirdy. 1974. Faba bean as a substitute for soybean meal or rapeseed meal in rations for lactating cows. Can. J. Anim. Sci. 54:87-89. http://dx.doi.org/10.4141/cjas74-013.

Ingalls, J. R., J. A. McKirdy, and H. R. Sharma. 1980. Nutritive value of fababeans in the diets of young Holstein calves and lactating dairy cows. Can. J. Anim. Sci. 60:689-698. http://dx.doi. org $/ 10.4141 /$ cjas80-080.

INRA. 2004. Tables of Composition and Nutritive Value of Feed Materials-Pigs, Poultry, Cattle, Sheep, Goats, Rabbits, Horses and Fish. D. Sauvant, J.-M. Perez and G. Tran, ed. Wageningen Academic Publishers, Wageningen, the Netherlands.

Jensen, E. S., M. B. Peoples, and H. Hauggaard-Nielsen. 2010. Faba bean in cropping systems. Field Crops Res. 115:203-216. http:// dx.doi.org/10.1016/j.fcr.2009.10.008.

Jezierny, D., R. Mosenthin, and E. Bauer. 2010. The use of grain legumes as a protein source in pig nutrition: A review. Anim. Feed Sci. Technol. 157:111-128. http://dx.doi.org/10.1016/j. anifeedsci.2010.03.001.

Korhonen, M., S. Ahvenjärvi, A. Vanhatalo, and P. Huhtanen. 2002. Supplementing barley or rapeseed meal to dairy cows fed grass-red clover silage: II. Amino acid profile of microbial fractions. J. Anim. Sci. 80:2188-2196.

Korhonen, M., A. Vanhatalo, T. Varvikko, and P. Huhtanen. 2000. Responses to graded postruminal doses of histidine in dairy cows fed grass silage diets. J. Dairy Sci. 83:2596-2608. http://dx.doi. org/10.3168/jds.S0022-0302(00)75153-8.

Lapierre, H., G. E. Lobley, L. Doepel, G. Raggio, H. Rulquin, and S. Lemosquet. 2012. Mammary metabolism of amino acids in dairy cows. J. Anim. Sci. 90:1708-1721. http://dx.doi.org/10.2527/ jas.2011-4645.

Larsen, M., P. Lund, M. R. Weisbjerg, and T. Hvelplund. 2009. Digestion site of starch from cereals and legumes in lactating dairy cows. Anim. Feed Sci. Technol. 153:236-248. http://dx.doi. org/10.1016/j.anifeedsci.2009.06.017.

Lee, C., A. N. Hristov, T. W. Cassidy, K. S. Heyler, H. Lapierre, G. A. Varga, M. J. de Veth, R. A. Patton, and C. Parys. 2012. Rumenprotected lysine, methionine, and histidine increase milk protein yield in dairy cows fed a metabolizable protein-deficient diet. J. Dairy Sci. 95:6042-6056. http://dx.doi.org/10.3168/jds.2012-5581.

Leonardi, C., M. Stevenson, and L. E. Armentano. 2003. Effect of two levels of crude protein and methionine supplementation on perfor- mance of dairy cows. J. Dairy Sci. 86:4033-4042. http://dx.doi. org/10.3168/jds.S0022-0302(03)74014-4.

Luke. 2015. Feed tables and nutrient requirements. Accessed July 1, 2015. http://www.mtt.fi/feedtables.

Martineau, R., D. R. Ouellet, and H. Lapierre. 2013. Feeding canola meal to dairy cows: A meta-analysis on lactational responses. J. Dairy Sci. 96:1701-1714. http://dx.doi.org/10.3168/jds.2012-5740.

Martineau, R., D. R. Ouellet, and H. Lapierre. 2014. The effect of feeding canola meal on concentrations of plasma amino acids. J. Dairy Sci. 97:1603-1610. http://dx.doi.org/10.3168/jds.2013-7125.

McCullough, H. 1967. The determination of ammonia in whole blood by direct colorimetric method. Clin. Chim. Acta 17:297-304. http://dx.doi.org/10.1016/0009-8981(67)90133-7.

Melicharová, V., A. Pechová, R. Dvořák, and L. Pavlata. 2009. Performance and metabolism of dairy cows fed bean seeds (Vicia faba) with different levels of anti-nutritional substances. Acta Vet. Brno 78:57-66. http://dx.doi.org/10.2754/avb200978010057.

Mogensen, L. P., J. S. Vestergaard, X. Fretté, P. Lund, M. R. Weisbjerg, and T. Kristensen. 2010. Effect of toasting field beans and grass-clover: Maize silage ratio on milk production, milk composition and sensory quality of milk. Livest. Sci. 128:123-132. http:// dx.doi.org/10.1016/j.livsci.2009.11.011.

Mordenti, A. L., F. Merendi, M. Fustini, and A. Formigoni. 2007. Effects of different protein plants in cows diet on milk for Parmigiano Reggiano production. Ital. J. Anim. Sci. 6(Suppl.1):463-465. http://dx.doi.org/10.4081/ijas.2007.1s.463.

Mould, F. L., E. R. Orskov, and S. O. Mann. 1983. Associative effects of mixed feeds. I. Effects of type and level of supplementation and the influence of the rumen fluid $\mathrm{pH}$ on cellulolysis in vivo and dry matter digestion of various roughages. Anim. Feed Sci. Technol. 10:15-30. http://dx.doi.org/10.1016/0377-8401(83)90003-2.

Nemecek, T., J.-S. von Richthofen, G. Dubois, P. Casta, R. Charles, and H. Pahl. 2008. Environmental impacts of introducing grain legumes into European crop rotations. Eur. J. Agron. 28:380-393. http://dx.doi.org/10.1016/j.eja.2007.11.004.

NRC. 2001. Nutrient Requirements of Dairy Cattle. 7th ed. National Academy Press, Washington, DC.

Offner, A., A. Bach, and D. Sauvant. 2003. Quantitative review of in situ starch degradation in the rumen. Anim. Feed Sci. Technol. 106:81-93. http://dx.doi.org/10.1016/S0377-8401(03)00038-5.

Olmos Colmenero, J. J., and G. A. Broderick. 2006. Effect of dietary crude protein concentration on milk production and nitrogen utilization in lactating dairy cows. J. Dairy Sci. 89:1704-1712. http:// dx.doi.org/10.3168/jds.S0022-0302(06)72238-X.

Rinne, M., K. Kuoppala, S. Ahvenjärvi, and A. Vanhatalo. 2015. Dairy cow responses to graded levels of rapeseed and soya bean expeller supplementation on a red clover/grass diet. Animal 9:1958-1969. http://dx.doi.org/10.1017/S1751731115001263.

Salin, S., J. Taponen, K. Elo, I. Simpura, A. Vanhatalo, R. Boston, and T. Kokkonen. 2012. Effects of abomasal infusion of tallow or camelina oil on responses to glucose and insulin in dairy cows during late pregnancy. J. Dairy Sci. 95:3812-3825. http://dx.doi. org/10.3168/jds.2011-5206.

Salo, M.-L. 1965. Determination of carbohydrate fractions in animal foods and faeces. Acta Agric. Fenn. 105:1-102.

Salo, M.-L., and M. Salmi. 1968. Determination of starch by the amyloglucosidase method. J. Sci. Agric. Soc. Finland 40:38-45.

Selim, S., S. Salin, J. Taponen, A. Vanhatalo, T. Kokkonen, and K. T. Elo. 2014. Prepartal dietary energy alters transcriptional adaptations of the liver and subcutaneous adipose tissue of dairy cows during the transition period. Physiol. Genomics 46:328-337. http://dx.doi.org/10.1152/physiolgenomics.00115.2013.

Sjaunja, L. O., L. Baevre, L. Junkkarinen, J. Pedersen, and J. A. Setälä. 1991. Nordic proposal for an energy-corrected milk (ECM) formula. Pages 156-157 in Performance Recordings of Animals: State of the Art, 1990. P. Gaillon and Y. Chabert, ed. EAAP Publication No. 50. PUDOC, Wageningen, the Netherlands.

Somogyi, M. 1945. A new reagent for the determination of sugars. J. Biol. Chem. 160:61-63 
Tufarelli, V., R. U. Khan, and V. Laudadio. 2012. Evaluating the suitability of field beans as a substitute for soybean meal in early-lactating dairy cow: Production and metabolic responses. Anim. Sci. J. 83:136-140. http://dx.doi.org/10.1111/j.17400929.2011.00934.x.

Valadares, R. F. D., G. A. Broderick, S. C. Valadares Filho, and M. K. Clayton. 1999. Effect of replacing alfalfa silage with high moisture corn on ruminal protein synthesis estimated from excretion of total purine derivatives. J. Dairy Sci. 82:2686-2696. http://dx.doi. org/10.3168/jds.S0022-0302(99)75525-6.

Van Keulen, J., and B. A. Young. 1977. Evaluation of acid-insoluble ash as a marker in ruminant digestibility studies. J. Anim. Sci. $44: 282-287$.

Van Soest, P. J., J. B. Robertson, and B. A. Lewis. 1991. Methods for dietary fiber, neutral detergent fiber, and nonstarch polysaccharides in relation to animal production. J. Dairy Sci. 74:3583-3597.

Vander Pol, M., A. N. Hristov, S. Zaman, and N. Delano. 2008. Peas can replace soybean meal and corn grain in dairy cow diets. J. Dairy Sci. 91:698-703. http://dx.doi.org/10.3168/jds.2007-0543.
Vanhatalo, A., S. Ahvenjarvi, and S. Jaakkola. 2004. Metabolic and production responses in dairy cows fed peas or rapeseed meal on grass silage based diets. J. Anim. Feed Sci. 13(Suppl. 1):231-234.

Vanhatalo, A., P. Huhtanen, V. Toivonen, and T. Varvikko. 1999 Response of dairy cows fed grass silage diets to abomasal infusions of histidine alone or in combinations with methionine and lysine. J. Dairy Sci. 82:2674-2685. http://dx.doi.org/10.3168/jds.S00220302(99)75524-4.

Vanhatalo, A., T. Varvikko, and P. Huhtanen. 2003. Effects of casein and glucose on responses of cows fed diets based on restrictively fermented grass silage. J. Dairy Sci. 86:3260-3270. http://dx.doi. org/10.3168/jds.S0022-0302(03)73929-0.

Wilkins, R. J., and R. Jones. 2000. Alternative home-grown protein sources for ruminants in the United Kingdom. Anim. Feed Sci. Technol. 85:23-32 